\title{
THERMODYNAMIC STUDY OF THE SOLUBILITY OF SODIUM NAPROXEN IN SOME ETHANOL + WATER MIXTURES
}

Daniel R. Delgado, Miller A. Ruidiaz, Sandra M. Gómez, Mauricio Gantiva e Fleming Martínez*

Departamento de Farmacia, Universidad Nacional de Colombia, A.A. 14490, Bogotá D.C., Colombia

Recebido em 10/3/10; aceito em 16/6/10; publicado na web em 24/9/10

\begin{abstract}
By using the van't Hoff and Gibbs equations the apparent thermodynamic functions Gibbs energy, enthalpy, and entropy of solution for sodium naproxen in ethanol + water cosolvent mixtures, were evaluated from solubility data determined at temperatures from ( 278.15 to 308.15 ) K. The drug solubility was greatest in neat water and lowest in neat ethanol at all the temperatures studied. By means of non-linear enthalpy-entropy compensation analysis, it follows that the dissolution process of this drug in ethanol-rich mixtures is entropy-driven, whereas, in water-rich mixtures the process is enthalpy-driven.
\end{abstract}

Keywords: cosolvency; sodium naproxen; solubility.

\section{INTRODUCTION}

Sodium naproxen (Na-NAP, Figure 1) is a non-steroidal antiinflammatory drug derived of propionic acid used widely as analgesic and antipyretic although it also is used for relief of symptoms of rheumatoid arthritis and osteoarthritis in addition to treatment of dysmenorrheal, among other indications. ${ }^{1}$ Although Na-NAP is widely used nowadays in therapeutics, the physicochemical information about their aqueous solutions is not complete at present, although several physicochemical studies have been done. Thus, the solution thermodynamics in neat aqueous media for this drug (as dissociate and non-dissociate compound) has been presented in the literature. ${ }^{2}$ In the same way, the solution thermodynamics as non-dissociate compound in some cosolvent mixtures has also been reported. ${ }^{3}$ Recently, Chavez studied the solubility of Na-NAP in some methanol + water and ethanol + water mixtures at several temperatures. ${ }^{4}$ Moreover, the physicochemical aspects of transfer of this drug (as non-dissociate compound) from aqueous media up to octanol and some phospholipidic vesicles have also been reported. ${ }^{5}$<smiles>COc1ccc2cc([C@@H](C)C(=O)O[Na])ccc2c1</smiles>

Figure 1. Molecular structure of sodium naproxen

On the other hand, it is well known that injectable homogeneous liquid formulations supply high doses of drug in small volumes, and thus, the solubility of drugs and other formulation components is very important, because it facilitate the design process of pharmaceutical dosage forms. ${ }^{6}$

As has been already described, the solubility behavior of drugs in cosolvent mixtures is very important because cosolvent blends are frequently used in purification methods, preformulation studies, and pharmaceutical dosage forms design, among other applications. ${ }^{7}$ For these reasons, it is important to determine systematically the solubility of pharmaceutical compounds. Besides, temperature-solubility dependence allows us to carry out the respective thermodynamic

*e-mail: fmartinezr@unal.edu.co analysis, which, on the other hand, also permits inside the molecular mechanisms, involved toward the solution processes. ${ }^{6}$

The main objective of this study was to evaluate the effect of the cosolvent composition on the solubility and solution thermodynamics of Na-NAP in ethanol $(\mathrm{EtOH})+$ water cosolvent mixtures based on the van't Hoff method as has been done earlier with procaine hydrochloride. ${ }^{8}$ Thus, this investigation amply the information reported by Chavez about the solubility of this drug in the same cosolvent system. ${ }^{4}$

\section{EXPERIMENTAL}

\section{Materials}

Sodium naproxen (d-2-(6-methoxy-2-naphthyl)propionic acid sodium salt; CAS: [26159-34-2]; purity: 0.9990 in mass fraction) used is in agreement with the quality requirements indicated in the American Pharmacopeia, USP; 9 on similar way, absolute ethanol A. R. (Merck) (CAS: 64-17-5; purity: 0.9990 in mass fraction), distilled water (CAS: 7732-18-5; conductivity $<2 \mu \mathrm{S} \mathrm{cm}^{-1}$ ), molecular sieve (Merck, numbers 3 and 4), and Millipore Corp. Swinnex ${ }^{\circledR}-13$ filter units, were also used in this study.

\section{Cosolvent mixtures preparation}

All EtOH + water cosolvent mixtures were prepared in quantities of $10.00 \mathrm{~g}$ by mass using an Ohaus Pioneer TM PA214 analytical balance with sensitivity $\pm 0.1 \mathrm{mg}$, in mass fractions from 0.10 to 0.90 varying by 0.10 , to study nine binary mixtures and the two pure solvents.

\section{Solubility determinations}

An excess of Na-NAP was added to $5 \mathrm{~cm}^{3}$ of each cosolvent mixture, in stoppered dark glass flasks. Solid-liquid mixtures were stirred in a mechanical shaker (Burrel, Wrist Action Shaker, Model 75 ) at room temperature at least for $4 \mathrm{~h}$. The flasks were kept at each temperature $( \pm 0.05 \mathrm{~K})$ in recirculating thermostatic baths (Neslab RTE 10 Digital One Thermo Electron Company) with sporadic stirring at least for 7 days to reach the equilibrium. After this time the supernatant solutions were filtered (at isothermal conditions) to ensure that they were free of particulate matter before 
sampling. Drug concentrations were determined by mass balance by weighting a specified quantity of the respective saturated solution and allowing the solvent evaporation up to constant mass. All the solubility experiments were run at least in triplicate. In order to make the equivalence between molarity and mole fraction concentration scales, the density of the saturated solutions was determined with a digital density meter (DMA 45 Anton Paar) connected to the same recirculating thermostatic baths.

\section{RESULTS AND DISCUSSION}

Before to show the solubility results, it is important to consider that this drug like procaine hydrochloride has electrolyte behavior, ${ }^{10}$ and thus, it dissociates in aqueous solution interacting with the cosolvent mixture by strong ion-dipole interactions, as well as by other weak non covalent interactions; on this way, it also could acts as a Lewis base $\left(-\mathrm{OCH}_{3}\right.$, Figure 1), in order to establish hydrogen bonds with proton-donor functional groups in the solvents (-OH groups). ${ }^{10}$

\section{Experimental solubility}

Tables 1 and 2 summarize the experimental solubility of $\mathrm{Na}$ $\mathrm{NAP}$, expressed in $\mathrm{mol} \mathrm{dm}{ }^{-3}$ and mole fraction, respectively, at all the temperatures studied. In all cases the percent coefficients of variation were smaller than $1.0 \%$.

It could be observed that the solubility expressed in both concentration scales was greatest in the mixture of 0.50 in mass fraction of EtOH at temperatures above $293.15 \mathrm{~K}$. This behavior shows cosolvent effect for this electrolyte drug in this solvent system, and it is not in agreement with that expected according to the literature, ${ }^{7}$ since the Na-NAP solubility is not greatest in neat water as could be expected because of its large dielectric constant value (78.5 at $298.15 \mathrm{~K}) .{ }^{10}$ Our solubility values in neat water are in good agreement with those reported by Mendez del $\mathrm{Rio}^{2}$ and by Kim et al., ${ }^{2}$ but they are so very different with respect to those reported by Martino et al.. ${ }^{2}$ In similar way, our solubility values in neat $\mathrm{EtOH}$ and those on mixtures of 0.30 and 0.90 in mass fraction of EtOH are in good agreement with those reported by Chavez. ${ }^{4}$ Unfortunately, in the literature there are not reported quantitative solubility values for this drug in other $\mathrm{EtOH}+$ water mixtures, and therefore, none other direct comparison is possible.

Because Na-NAP is an electrolyte drug, it is important to keep in mind that in general terms, it could be stated that a strong electrolyte dissociates according to the expression, $C_{v+} A_{v-} \rightarrow v_{+} C^{z+}+v_{-} A^{z-}$, where $v_{+}$is the number of cations $\left(C^{z+}\right)$ of valence $z+$ and $v_{-}$is the number of anions $\left(A^{z-}\right)$ of valence $z-$. Because it is not possible to determine experimentally the activity of ions separately, the concept of mean ionic activity $\left(a_{ \pm}^{v}\right)$ is used. Thus, the thermodynamic activity for an electrolyte can be defined as, $a_{2}=a_{+}^{v+} a_{-}^{v_{-}}=a_{ \pm}{ }^{{ }{ }^{11}}$

Na-NAP is an electrolyte solute of type one-one, that is, it dissociates in aqueous solutions to generate two species, a monovalent anion and a monovalent cation, respectively. If the inter-ionic interactions are not considered, in a first approach the $v$ value could be ideally assumed as 2 for this saline drug, and thus, this value could be used to calculate the apparent thermodynamic functions of solution. ${ }^{8,10}$

\section{Thermodynamic functions of solution}

According to van't Hoff analysis, the apparent standard enthalpy change of solution $\left(\Delta H_{\text {soln }}{ }^{\text {-app }}\right)$ for electrolytes type one-one, such as Na-NAP, if the inter-ionic interactions are not considered, is obtained by using the mean harmonic temperature $\left(T_{\mathrm{hm}}\right.$ is $292.8 \mathrm{~K}$ in the present case) according to Equation $1 .{ }^{8}$

Table 1. Experimental solubility of sodium naproxen in ethanol + water cosolvent mixtures expressed in mol $\mathrm{dm}^{-3}$ at several temperatures ${ }^{a}$

\begin{tabular}{|c|c|c|c|c|c|c|c|}
\hline \multirow[t]{2}{*}{$\mu_{\mathrm{EtOH}}^{b}$} & \multicolumn{7}{|c|}{$T / \mathrm{K}$} \\
\hline & 278.15 & 283.15 & 288.15 & 293.15 & 298.15 & 303.15 & 308.15 \\
\hline 0.00 & $\begin{array}{c}0.2137 \\
(0.0019)\end{array}$ & $\begin{array}{c}0.2983 \\
(0.0019)\end{array}$ & $\begin{array}{c}0.4081 \\
(0.0019)\end{array}$ & $\begin{array}{c}0.5504 \\
(0.0012)\end{array}$ & $\begin{array}{c}0.7298 \\
(0.0015)\end{array}$ & $\begin{array}{c}0.9389 \\
(0.0005)\end{array}$ & $\begin{array}{c}1.1811 \\
(0.0011)\end{array}$ \\
\hline 0.10 & $\begin{array}{c}0.1780 \\
(0.0015)\end{array}$ & $\begin{array}{c}0.2679 \\
(0.0011)\end{array}$ & $\begin{array}{c}0.3889 \\
(0.0007)\end{array}$ & $\begin{array}{c}0.5572 \\
(0.0017)\end{array}$ & $\begin{array}{c}0.7747 \\
(0.0016)\end{array}$ & $\begin{array}{c}1.0461 \\
(0.0011)\end{array}$ & $\begin{array}{c}1.3427 \\
(0.0025)\end{array}$ \\
\hline 0.20 & $\begin{array}{c}0.1694 \\
(0.0011)\end{array}$ & $\begin{array}{c}0.2772 \\
(0.0008)\end{array}$ & $\begin{array}{c}0.4570 \\
(0.0001)\end{array}$ & $\begin{array}{c}0.6649 \\
(0.0011)\end{array}$ & $\begin{array}{c}0.9192 \\
(0.0011)\end{array}$ & $\begin{array}{c}1.1346 \\
(0.0001)\end{array}$ & $\begin{array}{c}1.4191 \\
(0.0007)\end{array}$ \\
\hline 0.30 & $\begin{array}{c}0.2126 \\
(0.0015)\end{array}$ & $\begin{array}{c}0.3475 \\
(0.0015)\end{array}$ & $\begin{array}{c}0.5153 \\
(0.0018)\end{array}$ & $\begin{array}{c}0.7809 \\
(0.0015)\end{array}$ & $\begin{array}{c}0.9989 \\
(0.0026)\end{array}$ & $\begin{array}{c}1.2082 \\
(0.0017)\end{array}$ & $\begin{array}{c}1.4075 \\
(0.0002)\end{array}$ \\
\hline 0.40 & $\begin{array}{c}0.2751 \\
(0.0016)\end{array}$ & $\begin{array}{c}0.3976 \\
(0.0016)\end{array}$ & $\begin{array}{c}0.578 \\
(0.004)\end{array}$ & $\begin{array}{c}0.8233 \\
(0.0023)\end{array}$ & $\begin{array}{c}1.0161 \\
(0.0014)\end{array}$ & $\begin{array}{c}1.1915 \\
(0.0002)\end{array}$ & $\begin{array}{c}1.3626 \\
(0.0009)\end{array}$ \\
\hline 0.50 & $\begin{array}{c}0.3246 \\
(0.0007)\end{array}$ & $\begin{array}{c}0.4463 \\
(0.0004)\end{array}$ & $\begin{array}{c}0.5749 \\
(0.0007)\end{array}$ & $\begin{array}{c}0.7862 \\
(0.0011)\end{array}$ & $\begin{array}{c}0.9492 \\
(0.0002)\end{array}$ & $\begin{array}{c}1.0878 \\
(0.0025)\end{array}$ & $\begin{array}{c}1.2279 \\
(0.0003)\end{array}$ \\
\hline 0.60 & $\begin{array}{c}0.3456 \\
(0.0006)\end{array}$ & $\begin{array}{c}0.4315 \\
(0.0008)\end{array}$ & $\begin{array}{c}0.5128 \\
(0.0005)\end{array}$ & $\begin{array}{c}0.6597 \\
(0.0006)\end{array}$ & $\begin{array}{c}0.7852 \\
(0.0008)\end{array}$ & $\begin{array}{c}0.9020 \\
(0.0010)\end{array}$ & $\begin{array}{c}1.0294 \\
(0.0008)\end{array}$ \\
\hline 0.70 & $\begin{array}{c}0.2718 \\
(0.0003)\end{array}$ & $\begin{array}{c}0.3285 \\
(0.0006)\end{array}$ & $\begin{array}{c}0.3818 \\
(0.0008)\end{array}$ & $\begin{array}{c}0.4761 \\
(0.0033)\end{array}$ & $\begin{array}{c}0.5646 \\
(0.0037)\end{array}$ & $\begin{array}{c}0.6679 \\
(0.0050)\end{array}$ & $\begin{array}{c}0.7816 \\
(0.0006)\end{array}$ \\
\hline 0.80 & $\begin{array}{c}0.1665 \\
(0.0008)\end{array}$ & $\begin{array}{c}0.2019 \\
(0.0007)\end{array}$ & $\begin{array}{c}0.3438 \\
(0.0007)\end{array}$ & $\begin{array}{c}0.2856 \\
(0.0002)\end{array}$ & $\begin{array}{c}0.3438 \\
(0.0007)\end{array}$ & $\begin{array}{c}0.4101 \\
(0.0016)\end{array}$ & $\begin{array}{c}0.4849 \\
(0.0002)\end{array}$ \\
\hline 0.90 & $\begin{array}{c}0.1006 \\
(0.0005)\end{array}$ & $\begin{array}{c}0.1205 \\
(0.0002)\end{array}$ & $\begin{array}{c}0.1409 \\
(0.0007)\end{array}$ & $\begin{array}{c}0.1639 \\
(0.0007)\end{array}$ & $\begin{array}{c}0.1894 \\
(0.0002)\end{array}$ & $\begin{array}{c}0.2199 \\
(0.0016)\end{array}$ & $\begin{array}{c}0.2557 \\
(0.0001)\end{array}$ \\
\hline 1.00 & $\begin{array}{c}3.089(0.014) \\
\times 10^{-2}\end{array}$ & $\begin{array}{c}3.560(0.008) \\
\times 10^{-2}\end{array}$ & $\begin{array}{c}4.11(0.04) \\
\times 10^{-2}\end{array}$ & $\begin{array}{c}4.653(0.018) \\
\times 10^{-2}\end{array}$ & $\begin{array}{c}5.209(0.001) \\
\times 10^{-2}\end{array}$ & $\begin{array}{c}5.950(0.010) \\
\times 10^{-2}\end{array}$ & $\begin{array}{c}7.54(0.03) \\
\times 10^{-2}\end{array}$ \\
\hline
\end{tabular}

${ }^{a}$ Values in parentheses are standard deviations. ${ }^{b} \mu_{\mathrm{EtOH}}$ is the mass fraction of ethanol in the cosolvent mixture free of solute. 


$$
\left(\frac{\partial \ln x_{2}}{\partial\left(1 / T-1 / T_{\mathrm{hm}}\right)}\right)_{P}=-\frac{\Delta H_{\mathrm{soln}}^{0 \text { app }}}{2 R}
$$

where, $R$ is the universal gas constant $\left(8.314 \mathrm{~J} \mathrm{~mol}^{-1} \mathrm{~K}^{-1}\right)$. As an example, Figure 2 shows the modified van't Hoff plot for Na-NAP in mixtures containing 0.40, 0.60, and 0.80 in mass fraction of EtOH. For mixtures from 0.20 to 0.60 in mass fraction of $\mathrm{EtOH}$, parabolic models with good determination coefficients $\left(r^{2}\right)$ were obtained, while in the other solvent systems, linear models were obtained with good $\mathrm{r}^{2}$ values as well.

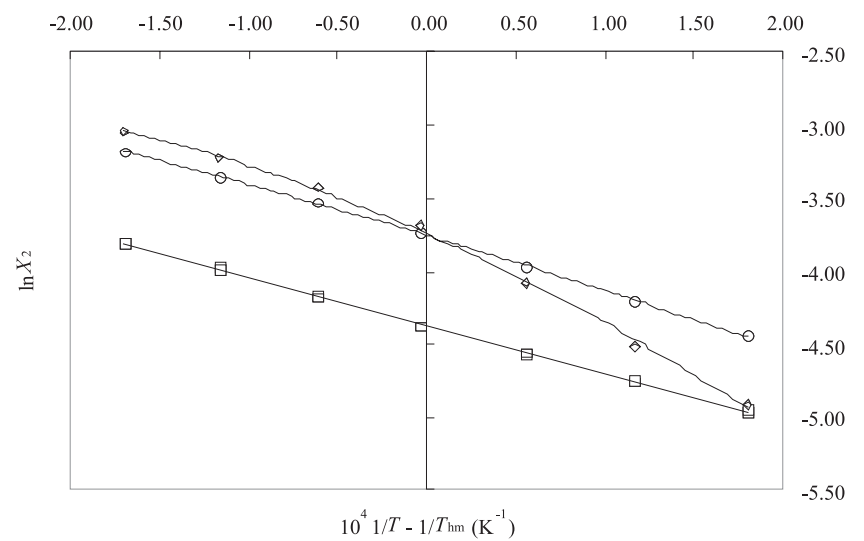

Figure 2. Modified van't Hoff plot for experimental solubility of sodium naproxen in some ethanol + water mixtures expressed in mole fraction. $(\diamond)$ : 0.40 in mass fraction of ethanol; (O): 0.60 in mass fraction of ethanol; ( $\square)$ : 0.80 in mass fraction of ethanol. The lines interconnecting points are the respective polynomial regression models
The apparent standard Gibbs energy change for the solution process $\left(\Delta G_{\text {soln }}{ }^{0 \text { app }}\right)$ of electrolytes type one-one, considering the approach proposed by Krug et al. ${ }^{12}$ is calculated at mean harmonic temperature by means of,

$$
\Delta G_{\text {soln }}^{0 \text {-app }}=-2 R T_{\mathrm{hm}} \times \text { intercept }
$$

in which, the intercept used is the one obtained in the analysis by treatment of $\ln x_{2}$ as a function of $1 / T-1 / T_{\mathrm{hm}}$. Finally, the apparent standard entropic change for solution process $\left(\Delta S_{\text {soln }}{ }^{\text {-app }}\right)$ is obtained from the respective $\Delta H_{\text {soln }}{ }^{\text {-app }}$ and $\Delta G_{\text {soln }}^{\text {0-app }}$ values by using:

$$
\Delta S_{\text {soln }}^{0 \text {-app }}=\frac{\left(\Delta H_{\text {soln }}^{0 \text {-app }}-\Delta G_{\text {soln }}^{0 \text {-app }}\right)}{T_{\mathrm{hm}}}
$$

Table 3 summarizes the apparent standard thermodynamic functions for experimental solution process of Na-NAP in all EtOH + water cosolvent mixtures. In order to calculate the thermodynamic quantities for the experimental solution processes some propagation of uncertainties' methods were used. ${ }^{13}$ It is found that the standard Gibbs energy of solution is positive in all cases as expected because the mole fraction is always lower than the unit and thus, its logarithmic term is negative, and therefore, standard Gibbs energy will be a positive quantity.

The apparent enthalpy of solution is positive in all cases, therefore the process is always endothermic. In the same way, the entropy of solution is also positive indicating entropy driving on overall the solution process for all the mixtures and neat solvents. The $\Delta H_{\text {soln }}{ }^{0 \text { app }}$ and $\Delta S_{\text {soln }}^{\text {0-app }}$ values increase from neat water up to the mixture of 0.20 in mass fraction of $\mathrm{EtOH}$ and decrease from this $\mathrm{EtOH}$ proportion up to neat $\mathrm{EtOH}$.

\begin{tabular}{|c|c|c|c|c|c|c|c|}
\hline \multirow[t]{2}{*}{$\mu_{\mathrm{EtOH}}^{b}$} & \multicolumn{7}{|c|}{$T / \mathrm{K}$} \\
\hline & 278.15 & 283.15 & 288.15 & 293.15 & 298.15 & 303.15 & 308.15 \\
\hline 0.00 & $\begin{array}{c}4.00 \\
(0.04)\end{array}$ & $\begin{array}{c}5.70 \\
(0.04)\end{array}$ & $\begin{array}{c}7.99 \\
(0.04)\end{array}$ & $\begin{array}{l}11.12 \\
(0.03)\end{array}$ & $\begin{array}{l}15.31 \\
(0.04)\end{array}$ & $\begin{array}{l}20.678 \\
(0.016)\end{array}$ & $\begin{array}{l}27.91 \\
(0.04)\end{array}$ \\
\hline 0.10 & $\begin{array}{c}3.58 \\
(0.03)\end{array}$ & $\begin{array}{c}5.503 \\
(0.026)\end{array}$ & $\begin{array}{c}8.170 \\
(0.016)\end{array}$ & $\begin{array}{l}12.08 \\
(0.04)\end{array}$ & $\begin{array}{l}17.70 \\
(0.05)\end{array}$ & $\begin{array}{l}25.71 \\
(0.04)\end{array}$ & $\begin{array}{l}36.00 \\
(0.03)\end{array}$ \\
\hline 0.20 & $\begin{array}{c}3.684 \\
(0.025)\end{array}$ & $\begin{array}{c}6.167 \\
(0.019)\end{array}$ & $\begin{array}{c}10.587 \\
(0.000)\end{array}$ & $\begin{array}{l}16.16 \\
(0.04)\end{array}$ & $\begin{array}{l}23.789 \\
(0.023)\end{array}$ & $\begin{array}{l}31.011 \\
(0.003)\end{array}$ & $\begin{array}{l}42.319 \\
(0.027)\end{array}$ \\
\hline 0.30 & $\begin{array}{c}5.08 \\
(0.04)\end{array}$ & $\begin{array}{c}8.60 \\
(0.04)\end{array}$ & $\begin{array}{l}13.35 \\
(0.06)\end{array}$ & $\begin{array}{l}21.28 \\
(0.05)\end{array}$ & $\begin{array}{l}28.85 \\
(0.10)\end{array}$ & $\begin{array}{l}36.94 \\
(0.07)\end{array}$ & $\begin{array}{l}45.597 \\
(0.011)\end{array}$ \\
\hline 0.40 & $\begin{array}{c}7.31 \\
(0.05)\end{array}$ & $\begin{array}{l}10.91 \\
(0.05)\end{array}$ & $\begin{array}{l}16.86 \\
(0.15)\end{array}$ & $\begin{array}{l}24.95 \\
(0.08)\end{array}$ & $\begin{array}{l}32.42 \\
(0.06)\end{array}$ & $\begin{array}{l}39.776 \\
(0.009)\end{array}$ & $\begin{array}{l}47.77 \\
(0.04)\end{array}$ \\
\hline 0.50 & $\begin{array}{c}9.718 \\
(0.023)\end{array}$ & $\begin{array}{c}13.728 \\
(0.013)\end{array}$ & $\begin{array}{l}18.82 \\
(0.03)\end{array}$ & $\begin{array}{l}26.20 \\
(0.04)\end{array}$ & $\begin{array}{l}32.899 \\
(0.006)\end{array}$ & $\begin{array}{l}39.30 \\
(0.13)\end{array}$ & $\begin{array}{l}46.165 \\
(0.019)\end{array}$ \\
\hline 0.60 & $\begin{array}{l}11.682 \\
(0.024)\end{array}$ & $\begin{array}{c}14.801 \\
(0.029)\end{array}$ & $\begin{array}{c}18.718 \\
(0.016)\end{array}$ & $\begin{array}{l}23.960 \\
(0.022)\end{array}$ & $\begin{array}{l}29.40 \\
(0.04)\end{array}$ & $\begin{array}{l}35.010 \\
(0.018)\end{array}$ & $\begin{array}{l}41.23 \\
(0.04)\end{array}$ \\
\hline 0.70 & $\begin{array}{c}10.184 \\
(0.011)\end{array}$ & $\begin{array}{c}12.491 \\
(0.027)\end{array}$ & $\begin{array}{c}15.495 \\
(0.034)\end{array}$ & $\begin{array}{l}18.86 \\
(0.15)\end{array}$ & $\begin{array}{l}22.89 \\
(0.18)\end{array}$ & $\begin{array}{l}27.71 \\
(0.26)\end{array}$ & $\begin{array}{l}33.47 \\
(0.03)\end{array}$ \\
\hline 0.80 & $\begin{array}{c}7.00 \\
(0.04)\end{array}$ & $\begin{array}{c}8.61 \\
(0.04)\end{array}$ & $\begin{array}{l}10.41 \\
(0.05)\end{array}$ & $\begin{array}{c}12.524 \\
(0.008)\end{array}$ & $\begin{array}{l}15.30 \\
(0.04)\end{array}$ & $\begin{array}{l}18.59 \\
(0.09)\end{array}$ & $\begin{array}{l}22.278 \\
(0.011)\end{array}$ \\
\hline 0.90 & $\begin{array}{c}4.888 \\
(0.024)\end{array}$ & $\begin{array}{c}5.919 \\
(0.013)\end{array}$ & $\begin{array}{c}7.00 \\
(0.03)\end{array}$ & $\begin{array}{c}8.19 \\
(0.04)\end{array}$ & $\begin{array}{c}9.601 \\
(0.012)\end{array}$ & $\begin{array}{c}11.24 \\
(0.09)\end{array}$ & $\begin{array}{l}13.220 \\
(0.002)\end{array}$ \\
\hline 1.00 & $\begin{array}{c}1.781 \\
(0.008)\end{array}$ & $\begin{array}{c}2.065 \\
(0.005)\end{array}$ & $\begin{array}{c}2.392 \\
(0.020)\end{array}$ & $\begin{array}{c}2.723 \\
(0.011)\end{array}$ & $\begin{array}{c}3.074 \\
(0.000)\end{array}$ & $\begin{array}{c}3.538 \\
(0.006)\end{array}$ & $\begin{array}{c}3.913 \\
(0.019)\end{array}$ \\
\hline
\end{tabular}

With the aim to compare the relative contributions by enthalpy

Table 2. Experimental solubility of sodium naproxen in ethanol + water cosolvent mixtures expressed as $1000 \times$ mole fraction at several temperatures ${ }^{a}$

${ }^{a}$ Values in parentheses are standard deviations. ${ }^{b} \mu_{\mathrm{EtOH}}$ is the mass fraction of ethanol in the cosolvent mixture free of solute. 
Table 3. Apparent thermodynamic functions relative to solution process of sodium naproxen in ethanol + water cosolvent mixtures at $292.8 \mathrm{~K}$

\begin{tabular}{|c|c|c|c|c|c|c|}
\hline$\underline{\mu_{\mathrm{EtOH}}{ }^{a}}$ & $\Delta G_{\text {soln }}{ }^{\text {-app }} / \mathrm{kJ} \mathrm{mol}^{-1}$ & $\Delta H_{\text {soln }}^{\text {0-app }} / \mathrm{kJ} \mathrm{mol}^{-1}$ & $\Delta S_{\text {soln }}{ }^{0 \text {-app }} / \mathrm{J} \mathrm{mol}^{-1} \mathrm{~K}^{-1}$ & $T \Delta S_{\text {soln }}^{0 \text {-app }} / \mathrm{kJ} \mathrm{mol}^{-1}$ & $\zeta_{H}^{b}$ & $\zeta_{T S}{ }^{b}$ \\
\hline 0.00 & $22.019(0.005)$ & $92.27(0.07)$ & $239.9(0.2)$ & $70.25(0.06)$ & 0.568 & 0.432 \\
\hline 0.10 & $21.616(0.008)$ & $109.8(0.1)$ & $301.1(0.3)$ & $88.18(0.10)$ & 0.555 & 0.445 \\
\hline 0.20 & $20.25(0.04)$ & $115.1(0.4)$ & $323.9(1.2)$ & $94.8(0.3)$ & 0.548 & 0.452 \\
\hline 0.30 & $19.03(0.04)$ & $103.8(0.4)$ & $289.5(1.2)$ & $84.8(0.3)$ & 0.550 & 0.450 \\
\hline 0.40 & $18.24(0.05)$ & $89.6(0.4)$ & $243.8(1.4)$ & $71.4(0.4)$ & 0.557 & 0.443 \\
\hline 0.50 & $17.94(0.03)$ & $74.24(0.29)$ & $192.3(0.8)$ & $56.30(0.24)$ & 0.569 & 0.431 \\
\hline 0.60 & $18.290(0.020)$ & $60.53(0.19)$ & $144.3(0.5)$ & $42.24(0.14)$ & 0.589 & 0.411 \\
\hline 0.70 & $19.383(0.007)$ & $56.55(0.10)$ & $126.9(0.2)$ & $37.17(0.07)$ & 0.603 & 0.397 \\
\hline 0.80 & $21.301(0.010)$ & $54.98(0.15)$ & $115.0(0.3)$ & $33.68(0.09)$ & 0.620 & 0.380 \\
\hline 0.90 & $23.425(0.008)$ & $46.68(0.11)$ & $79.42(0.20)$ & $23.25(0.06)$ & 0.667 & 0.333 \\
\hline 1.00 & $28.811(0.011)$ & $37.21(0.16)$ & $28.67(0.12)$ & $8.40(0.04)$ & 0.816 & 0.184 \\
\hline
\end{tabular}

${ }^{a} \mu_{\mathrm{E} \mathrm{IH}}$ is the mass fraction of ethanol in the cosolvent mixture free of solute. ${ }^{b} \zeta_{H}$ and $\zeta_{T S}$ are the relative contributions by enthalpy and entropy toward Gibbs energy of solution. These values were calculated by means of Equations 4 and 5 , respectively.

$\left(\zeta_{H}\right)$ and by entropy $\left(\zeta_{T S}\right)$ toward the solution process, Equations 4 and 5 were employed, respectively. ${ }^{14}$

$$
\begin{aligned}
& \zeta_{H}=\frac{\left|\Delta H_{\mathrm{soln}}^{0}\right|}{\left|\Delta H_{\mathrm{soln}}^{0}\right|+\left|T \Delta S_{\mathrm{soln}}^{0}\right|} \\
& \zeta_{T S}=\frac{\left|T \Delta S_{\mathrm{soln}}^{0}\right|}{\left|\Delta H_{\mathrm{soln}}^{0}\right|+\left|T \Delta S_{\mathrm{soln}}^{0}\right|}
\end{aligned}
$$

From Table 3 it follows that enthalpy is the main contributor to standard Gibbs energy of solution process of Na-NAP in all the systems studied, and thus the energetic factor predominate, in particular for neat $\mathrm{EtOH}$.

\section{Thermodynamic functions of transfer}

In order to verify the effect of cosolvent composition on the thermodynamic function driving the solution process, Table 4 summarizes the thermodynamic functions of transfer of Na-NAP from the more polar solvents to the less polar ones. These new functions were calculated as the differences between the thermodynamic quantities of solution in the more polar mixtures and the less polar mixtures.

Table 4. Apparent thermodynamic functions of transfer of sodium naproxen from more polar solvents to less polar solvents in ethanol + water cosolvent mixtures at $292.8 \mathrm{~K}$

\begin{tabular}{llcccc}
\hline $\begin{array}{l}\mu_{\mathrm{EiOH}}{ }^{a} \\
\mathrm{~A}\end{array}$ & $\mathrm{~B}$ & $\begin{array}{c}\Delta G_{\mathrm{A} \rightarrow \mathrm{B}}^{0 \text {-app }} \\
\mathrm{kJ} \mathrm{mol}^{-1}\end{array}$ & $\begin{array}{c}\Delta H_{\mathrm{A} \rightarrow \mathrm{B}}^{0 \text {-app }} \\
\mathrm{kJ} \mathrm{mol}^{-1}\end{array}$ & $\begin{array}{c}\Delta S_{\mathrm{A} \rightarrow-\mathrm{app} /}^{0} \\
\mathrm{~J} \mathrm{~mol}^{-1} \mathrm{~K}^{-1}\end{array}$ & $\begin{array}{c}T \Delta S_{\mathrm{A} \rightarrow \mathrm{B}}^{0 \text {-app }} \\
\mathrm{kJ} \mathrm{mol}^{-1}\end{array}$ \\
\hline 0.00 & 0.20 & $-1.77(0.04)$ & $22.8(0.4)$ & $84.0(1.2)$ & $24.6(0.3)$ \\
0.20 & 0.50 & $-2.31(0.05)$ & $-40.9(0.5)$ & $-131.6(1.4)$ & $-38.5(0.4)$ \\
0.50 & 1.00 & $10.87(0.03)$ & $-37.0(0.3)$ & $-163.6(0.8)$ & $-47.91(0.25)$ \\
\hline
\end{tabular}

${ }^{a} \mu_{\mathrm{EtOH}}$ is the mass fraction of ethanol in the cosolvent mixture free of solute; $\mathrm{A}$ and $\mathrm{B}$ are the more polar and less polar media, respectively.

If the addition of EtOH to neat water is considered (being the cosolvent mixture less polar as the EtOH proportion increases), as has been done earlier, ${ }^{8}$ it happens the following, from pure water to 0.20 in mass fraction of $\operatorname{EtOH}\left(\Delta G_{\mathrm{A} \rightarrow \mathrm{B}}^{0 \text {-app }}<0, \Delta H_{\mathrm{A} \rightarrow \mathrm{B}}^{0 \text {-app }}>0\right.$, and $\left.\Delta S_{\mathrm{A} \rightarrow \mathrm{B}}^{0 \text {-app }}>0\right)$ the solubility process is driven by the entropy; whereas, from this com-

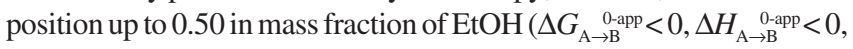

and $\left.\Delta S_{\mathrm{A} \rightarrow \mathrm{B}}^{0 \text {-app }}<0\right)$ the dissolution process is enthalpy driven. Ulti-

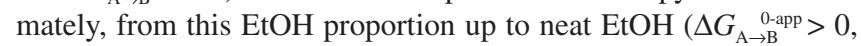

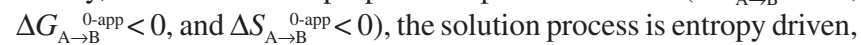
again. Nevertheless, the molecular or ionic events involved on solution processes are unclear.

\section{Enthalpy-entropy compensation of solution}

According to the literature, the making of weighted graphs of $\Delta G_{\text {soln }}^{\text {0-app }}$ as a function of $\Delta G_{\text {soln }}^{\text {0-app }}$ at mean harmonic temperature allows us to observe similar mechanisms for the solution process according to the tendencies obtained. ${ }^{15}$

In this context, Figure 3 shows fully that Na-NAP in the EtOH + water cosolvent system exhibits non-linear $\Delta H_{\text {soln }}{ }^{0 \text {-app }}$ vs. $\Delta G_{\text {soln }}{ }^{0 \text {-app }}$ compensation with negative slope if an interval from pure water up to 0.20 in mass fraction of EtOH is considered, whereas from this EtOH proportion to 0.50 in mass fraction of EtOH neat water a positive slope is obtained. Accordingly to this graph it follows that the driving function for drug solubility is the entropy in the former case, while in the second case, the driving function is mainly the enthalpy. On the other hand, from 0.50 in mass fraction of $\mathrm{EtOH}$ to neat $\mathrm{EtOH}$ negative slope is found again indicating entropy driven again, as it was already said in terms of quantities

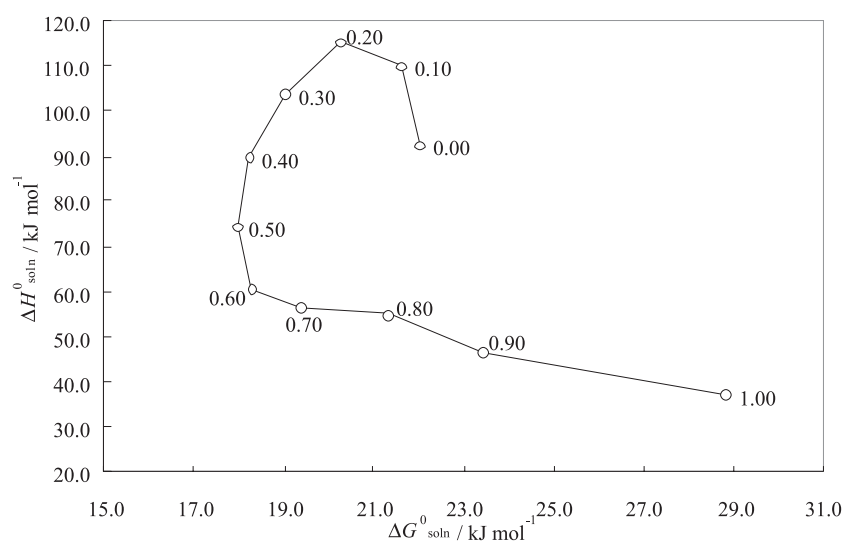

Figure 3. $\Delta H_{\text {soln }}^{o}$ vs. $\Delta G_{\text {soln }}^{0}$ enthalpy-entropy compensation plot for solubility of sodium naproxen in ethanol + water cosolvent mixtures at $292.8 \mathrm{~K}$. The slopes of the lines interconnecting composition points (mass fractions of ethanol) define the thermodynamic functions driving the sodium naproxen transfer processes 
of transfer. Nevertheless, the molecular and ionic events involved in the dissolution of this drug in this cosolvent system are unclear as was already said.

\section{CONCLUSIONS}

From all topics discussed previously it can be concluded that the solution process of Na-NAP in EtOH + water mixtures is variable depending on the cosolvent composition. Non linear enthalpy-entropy compensation was found for this electrolyte drug in this cosolvent system. In this context, entropy-driving was found for the solution processes in compositions from pure water to the mixture having 0.20 in mass fraction of $\mathrm{EtOH}$; whereas, for cosolvent mixtures from this EtOH proportion to mixture of 0.50 in mass fraction of EtOH, enthalpy-driving was found; moreover, beyond this $\mathrm{EtOH}$ proportion up to neat EtOH entropy-driving is found again. Ultimately, it can be said that the data presented in this report expand the physicochemical information about electrolyte drugs in aqueous solutions.

\section{ACKNOWLEDGMENTS}

We thank the DIB of the Universidad Nacional de Colombia (UNC) for the financial support. Additionally we thank the Department of Pharmacy of UNC for facilitating the equipment and laboratories used.

\section{REFERENCES}

1. Raffa, R. B. In Remington: The Science and Practice of Pharmacy, $21^{\text {st }}$ ed.; Gennaro, A. R., ed.; Lippincott Williams \& Wilkins: Philadelphia, 2005, p. 1539

2. Martino, P. D.; Barthelemy, C.; Palmieri, G. F.; Martelli, S.; Eur. J. Pharm. Sci. 2001, 14, 293; Perlovich, G. L.; Kurkov, S. V.; Kinchin, A. N.; Bauer-Brandl, A.; Eur. J. Pharm. Biopharm. 2004, 57, 411; Méndez del Río, J. R.; M.Sc. Thesis, Georgia Institute of Technology, Atlanta, 2004; Kim, Y. S.; Méndez del Río, J. R.; Rousseau, R. W.; J. Pharm. Sci. 2005, 94, 1941; Mora, C. P.; Martínez, F.; Phys. Chem. Liq. 2006, 44, 585; Mora, C. P.; Barbosa, H. J.; Martínez, F.; Vitae, Rev. Fac. Quím. Farm. 2007, 14, 38 .
3. Bustamante, P.; Peña, M. A.; Barra, J.; J. Pharm. Pharmacol. 1998, 50, 975; Pacheco, D. P.; Martínez, F.; Phys. Chem. Liq. 2007, 45, 581; Manrique, Y. J.; Pacheco, D. P.; Martínez, F.; J. Solution Chem. 2008, 37,165

4. Chavez, K. J.; Ph.D. Thesis, Georgia Institute of Technology, Atlanta, 2009.

5. Mora, C. P.; Martínez, F.; J. Chem. Eng. Data 2007, 52, 1933.

6. Jiménez, J. A.; Martínez, F.; J. Solution Chem. 2006, 35, 335.

7. Rubino, J. T. In Encyclopedia of Pharmaceutical Technology; Swarbrick, J.; Boylan J. C., eds.; Marcel Dekker, Inc.: New York, 1988, vol 3, p. 375-398; Yalkowsky, S. H.; Solubility and Solubilization in Aqueous Media, American Chemical Society and Oxford University Press: New York, 1999, p. 91-134.

8. Delgado, D. R.; Vargas, E. F.; Martínez, F.; J. Chem. Eng. Data 2010, 55, 2900.

9. US Pharmacopeia, $23^{\text {rd }}$ ed., The United States Pharmacopeial Convention: Rockville, MD, 1994, p. 1054-1055.

10. Martin, A.; Bustamante, P.; Chun, A. H. C.; Physical Pharmacy: Physical Chemical Principles in the Pharmaceutical Sciences, $4^{\text {th }}$ ed., Lea \& Febiger: Philadelphia, 1993; Florence, A. T.; Atwood, D.; Physicochemical Principles of Pharmacy, $3^{\text {rd }}$ ed., MacMillan Press Ltd.: London, 1998, p. 64-67.

11. Klotz, I. M.; Rosenberg, R. M.; Chemical Thermodynamics: Basic Theory and Methods, $6^{\text {th }}$ ed.; John Wiley \& Sons, Inc.: New York, 2000, p. 438-448; Bevan, J.; Boerio-Goates, J.; Chemical Thermodynamics: Principles and Applications, Academic Press: New York, 2000, p. 295301; Connors, K. A.; Thermodynamics of Pharmaceutical Systems: An Introduction for Students of Pharmacy, Wiley-Interscience: Hoboken, 2002, p. 96-105.

12. Krug, R. R.; Hunter, W. G.; Grieger, R. A.; J. Phys. Chem. 1976, 80, 2341.

13. Bevington, P. R.; Data Reduction and Error Analysis for the Physical Sciences, McGraw-Hill Book Co.: New York, 1969, p. 56-91.

14. Perlovich, G. L.; Kurkov, S. V.; Kinchin, A. N.; Bauer-Brandl, A.; Eur. J. Pharm. Biopharm. 2004, 57, 411.

15. Bustamante, P.; Romero, S.; Reillo, A.; Pharm. Sci. 1995, 1, 505; Tomlinson, E.; Int. J. Pharm. 1983, 13, 115. 